\title{
Treatment Strategies for ARID1A-Deficient Ovarian Clear Cell Carcinoma
}

\author{
Kazuaki Takahashi ${ }^{1,2,3}$, Masataka Takenaka ${ }^{1}$, Aikou Okamoto ${ }^{1}$, David D. L. Bowtell ${ }^{2,4}$ and Takashi Kohno ${ }^{3, *}$ \\ 1 Department of Obstetrics and Gynecology, Jikei University School of Medicine, Tokyo 105-8461, Japan; \\ Kazuaki.Takahashi@petermac.org (K.T.); tt10mm10@jikei.ac.jp (M.T.); aikou@jikei.ac.jp (A.O.) \\ 2 Peter MacCallum Cancer Centre, Melbourne, VIC 3000, Australia; david.bowtell@petermac.org \\ 3 Division of Genome Biology, National Cancer Center Research Institute, Tokyo 104-0045, Japan \\ 4 Sir Peter MacCallum Department of Oncology, The University of Melbourne, Parkville, VIC 3010, Australia \\ * Correspondence: tkkohno@ncc.go.jp
}

check for updates

Citation: Takahashi, K.; Takenaka, M.; Okamoto, A.; Bowtell, D.D.L.; Kohno, T. Treatment Strategies for ARID1A-Deficient Ovarian Clear Cell Carcinoma. Cancers 2021, 13, 1769. https://doi.org/10.3390/

cancers13081769

Academic Editor: Michael W. Krainer

Received: 17 February 2021

Accepted: 31 March 2021

Published: 7 April 2021

Publisher's Note: MDPI stays neutral with regard to jurisdictional claims in published maps and institutional affiliations.

Copyright: (c) 2021 by the authors. Licensee MDPI, Basel, Switzerland. This article is an open access article distributed under the terms and conditions of the Creative Commons Attribution (CC BY) license (https:/ / creativecommons.org/licenses/by/ $4.0 /)$.
Simple Summary: Deleterious mutations in SWI/SNF chromatin remodeling genes, such as ARID1A, are present in more than $50 \%$ of cases of ovarian clear cell carcinoma (OCCC), a histological subtype of ovarian cancer prevalent in Asian countries. To efficiently treat OCCC, which is refractory to conventional platinum-based chemotherapy, several therapeutic strategies based on SWI/SNF deficiency have been proposed, including gemcitabine-based chemotherapy, synthetic lethal therapy, and immune checkpoint blockade therapy. Implementation of these strategies would improve the prognosis of patients with this disease.

Abstract: Ovarian clear cell carcinoma (OCCC) is a histological subtype of ovarian cancer that is more frequent in Asian countries ( $25 \%$ of ovarian cancers) than in US/European countries (less than $10 \%$ ). OCCC is refractory to conventional platinum-based chemotherapy, which is effective against highgrade serous carcinoma (HGSC), a major histological subtype of ovarian cancer. Notably, deleterious mutations in SWI/SNF chromatin remodeling genes, such as ARID1A, are common in OCCC but rare in HGSC. Because this complex regulates multiple cellular processes, including transcription and DNA repair, molecularly targeted therapies that exploit the consequences of SWI/SNF deficiency may have clinical efficacy against OCCC. Three such strategies have been proposed to date: prioritizing a gemcitabine-based chemotherapeutic regimen, synthetic lethal therapy targeting vulnerabilities conferred by SWI/SNF deficiency, and immune checkpoint blockade therapy that exploits the high mutational burden of ARID1A-deficient tumor. Thus, ARID1A deficiency has potential as a biomarker for precision medicine of ovarian cancer.

Keywords: ovarian clear cell carcinoma; ARID1A; synthetic lethality; gemcitabine; molecular targeted therapy; precision medicine

\section{Introduction}

Ovarian clear cell carcinoma (OCCC) is a histological subtype of ovarian cancer that constitutes $25 \%$ of ovarian cancers in Asian countries, but less than $10 \%$ of ovarian cancers in US and European countries [1-3]. OCCC is more refractory to conventional platinum-based chemotherapy than other major histological types of ovarian cancer, such as high-grade serous carcinoma (HGSC) [4]; the response rate in OCCC is $11-56 \%$, whereas that in HGSC is about 80\% [5-7]. Because OCCC is rare in US and European countries, OCCC cases have not been actively enrolled into clinical trials, and clinical trials specifically targeting OCCC have been highly limited [8]. Consequently, effective treatment strategies for OCCC (i.e., precision medicine) have not yet been established [4,9].

OCCC is characterized by genetic alterations distinct from those found in HGSC, including frequent deficiency of genes encoding subunit proteins of the SWI/SNF chromatin remodeling complexes. The nucleosome, the basic unit of chromatin, is composed 
of 146 pairs of DNA bases wrapped around histone protein octamers. Nucleosomes prevent the binding of transcription factors and histone modifiers in the nucleus. Chromatin remodeling complexes regulate gene expression, DNA replication and repair, and cell division through changes in chromatin structure. The SWI/SNF complexes, which comprise tens of subunit proteins, obtain energy from ATP hydrolysis to cause nucleosome sliding, exposing specific regions of DNA and allowing interaction with histone modifiers [10]. The ARID1A gene, which encodes the BAF250A/ARID1A protein, is the most frequently mutated SWI/SNF subunit gene in OCCC, although several other subunit genes, including SMARCA4 and ARID1B, are also mutated [11]. ARID1A mutations, most of which are deleterious, are detected in about $50 \%$ of OCCCs, and loss of BAF250A/ARID1A protein, which functions as a regulatory subunit of the SWI/SNF complex, is observed at a similar frequency [12,13]. Interestingly, loss of BAF250A/ARID1A protein expression is observed not only in homozygous but also in heterozygous mutants. A previous study reported the post-transcriptional/translational effects of ARID1A mutation [13]. Several studies reported that knockout of the ARID1A gene impairs transcriptional and DNA repair activities within cells $[14,15]$; therefore, the function of the SWI/SNF complex is (at least partially) lost in half of OCCC cases. In this review, we focus on the properties of OCCC and possible precision medicine for this cancer from the standpoint of deficiency in SWI/SNF-mediated chromatin remodeling.

\section{Inter-Ethnic Differences in the Prevalence of OCCC}

The proportion of OCCC among the four major histological types of epithelial ovarian cancer is higher in Asia (about 25\%) than in Europe and the US (less than 10\%) [1-3]. The proportions in Japan, the US, and Australia are shown in Figure 1a. The data from Japan and the US are from the Japan Society of Obstetrics and Gynecology tumor registry database and the Surveillance, Epidemiology, and End Results (SEER) program (2002-2015) [16], respectively, whereas the data from Australia is from a nationwide epidemiological survey conducted by the Australian Ovarian Cancer Study between 2001 and 2005 [17-19]. The Japanese cohort included a higher fraction (27\%) of OCCC than the US ( $8 \%$ ) and Australian $(8 \%)$ cohorts, respectively.
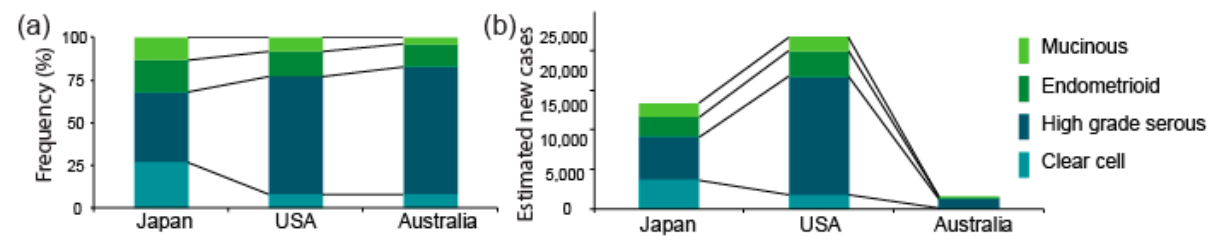

Figure 1. Proportions of OCCC and estimated numbers of new OCCC cases per year. (a) Proportions of OCCC among all epithelial ovarian cancers in Japan, the US, and Australia, using data obtained respectively from the Cancer Information Service, "Projected cancer incidence in 2020" Available online: https:/ / ganjoho.jp/reg_stat/statistics/stat/short_pred.html (accessed on 19 November 2020); American Cancer Society, “Cancer Facts \& Figures 2020”. Available online: https:/ /www.cancer.org/ research/cancer-facts-statistics / all-cancer-facts-figures / cancer-facts-figures-2020.html (accessed on 19 November 2020) and Cancer Australia, "Ovarian cancer statistics in Australia". Available online: https: / /www.canceraustralia.gov.au/affected-cancer/cancer-types/ovarian-cancer/ovariancancer-statistics-australia (accessed on 19 November 2020) (b) Estimated numbers of new OCCC cases per year in Japan, the US, and Australia. The numbers were estimated based on the projected numbers of ovarian cancer patients and the proportions of OCCC in (a).

We estimated the numbers of new OCCC cases per year based on the projected number of ovarian cancer patients (PNP) in Japan, the US, and Australia in 2020, and the proportion of OCCC among all ovarian cancers, given above. The number of patients with OCCC, which we estimated by multiplying the PNP by the proportion of OCCC in each cohort, is shown in Figure 1b. The number of overall ovarian cancer cases is smaller in Japan $(13.4 \mathrm{~K})$ than in the US $(21.8 \mathrm{~K})$, whereas the number of OCCC cases is likely to be 2-fold 
greater in Japan $(3.6 \mathrm{~K})$ than in the US $(1.7 \mathrm{~K})$. This estimate indicates that not only the proportion but also the absolute number of OCCC patients is larger in Asia (using Japan as a representative) than in the US. The reasons for such inter-ethnic differences are unknown. However, these calculations validate the idea that OCCC is a particularly problematic disease in Japan and other Asian countries.

\section{ARID1A and Other SWI/SNF Gene Alterations in OCCC}

Multiple genes encoding subunits of the SWI/SNF complexes, including ARID1A, $S M A R C A 4, P B R M 1$, and SMARCB1, are mutated in $\sim 20 \%$ of all cancers $[20,21]$. In particular, several pan-cancer genome-wide studies repeatedly identified ARID1A as one of the top 10 most frequently mutated genes [22-24]. In particular, OCCC is frequently associated with $A R I D 1 A$ mutations [12,13], while other SWI/SNF subunit genes, such as ARID1B and SMARCA4, are also mutated in a subset of OCCC [11]. Mutation frequencies of SWI/SNF subunit genes in the project GENIE database (v8.1), which accumulated data from gene profiling tests performed in daily oncology practice in the US [25], are shown in Figure 2a,b. $A R I D 1 A$ is the most frequently mutated SWI/SNF gene, followed by ARID1B, SMARCA4, $A R I D 2$, and PBRM1. The mutation frequencies of these genes according to tumor type are shown in Figure $2 \mathrm{c}-\mathrm{g}$. The distribution of mutations in genes related to SWI/SNF complexes is not random; rather, such mutations are more common in certain cancer types [26]. Evidently, frequent ARID1A mutation is a genetic property of OCCC. ARID1A mutations are detected in adjacent endometriotic lesions of OCCC, but not in distant endometriosis in the same patient, indicating that OCCC arises from endometriosis, and that ARID1A functions as a major tumor suppressor during development of OCCC [13,27-29].

(a)

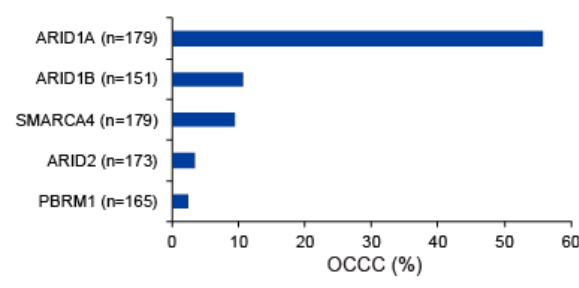

(b)

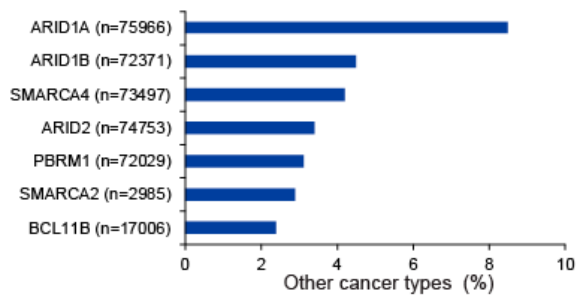

(c)

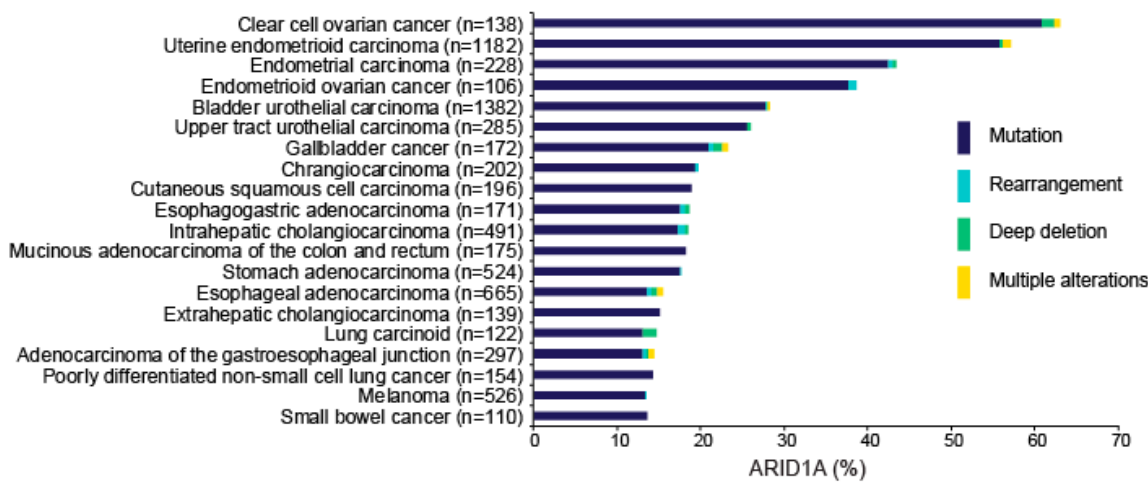

Figure 2. Cont. 
(d)

Cutaneous squamous cell carcinoma $(n=194)$ Mucinous adenocarine endometrioid carcinoma $(n=1178)$ rcinoma of the colon and rectum $(n=171)$ Endometrial carcinoma $(n=22)$ Clear cell ovarian cancer $(n=135)$ Anaplastic oligodendroglioma $(n=155)$ Cutaneous melanoma $(n=957)$ unk primary $(n=210)$ Small bowel cancer $(n=207)$ Bladder urothelial carcinoma $(n=1374)$ Endometrioid ovarian cancer $(n=105)$ Merkel cell carcinoma $(n=223)$ Poorly differentiated carcinoma, NOS $(n=212)$. Oligodendroglioma $(n=22)$ Neuroendocrine carcinoma, NOS $(n=127)$
Colon adenocarcinoma $(n=3629)$ Esophagogastric adenocarcinom Cholangiocarcinoma $(n=198)$

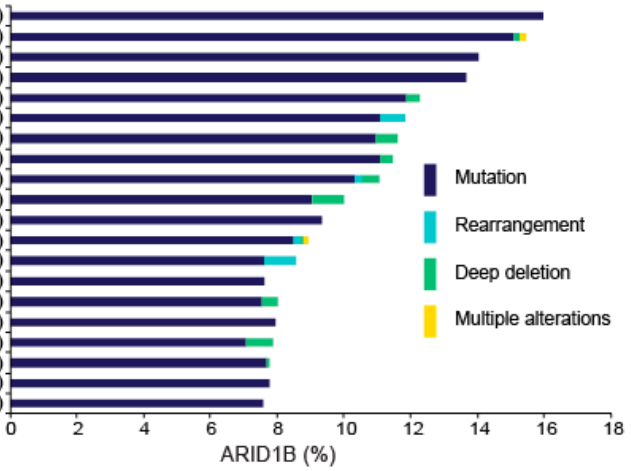

(e)

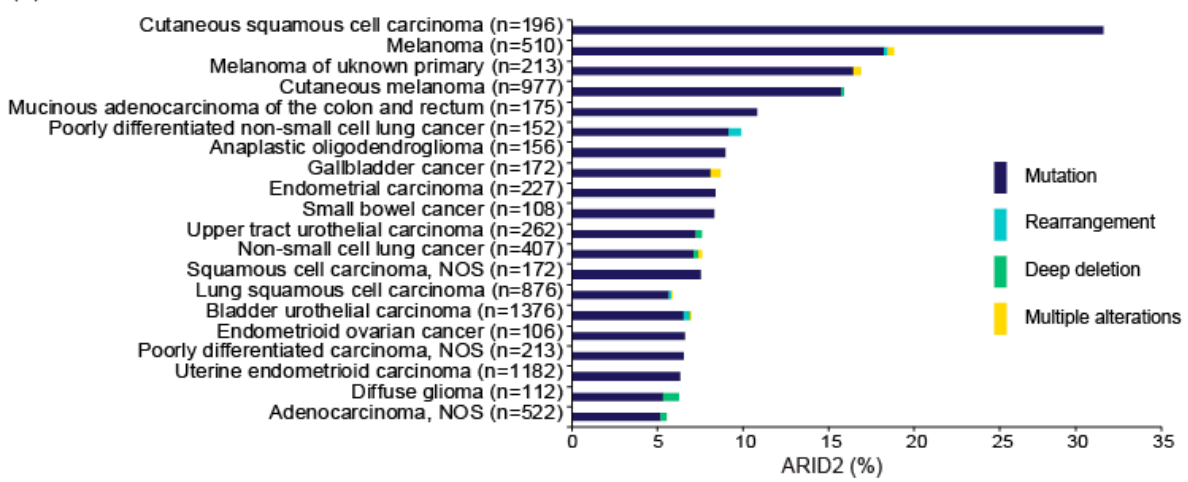

(f)

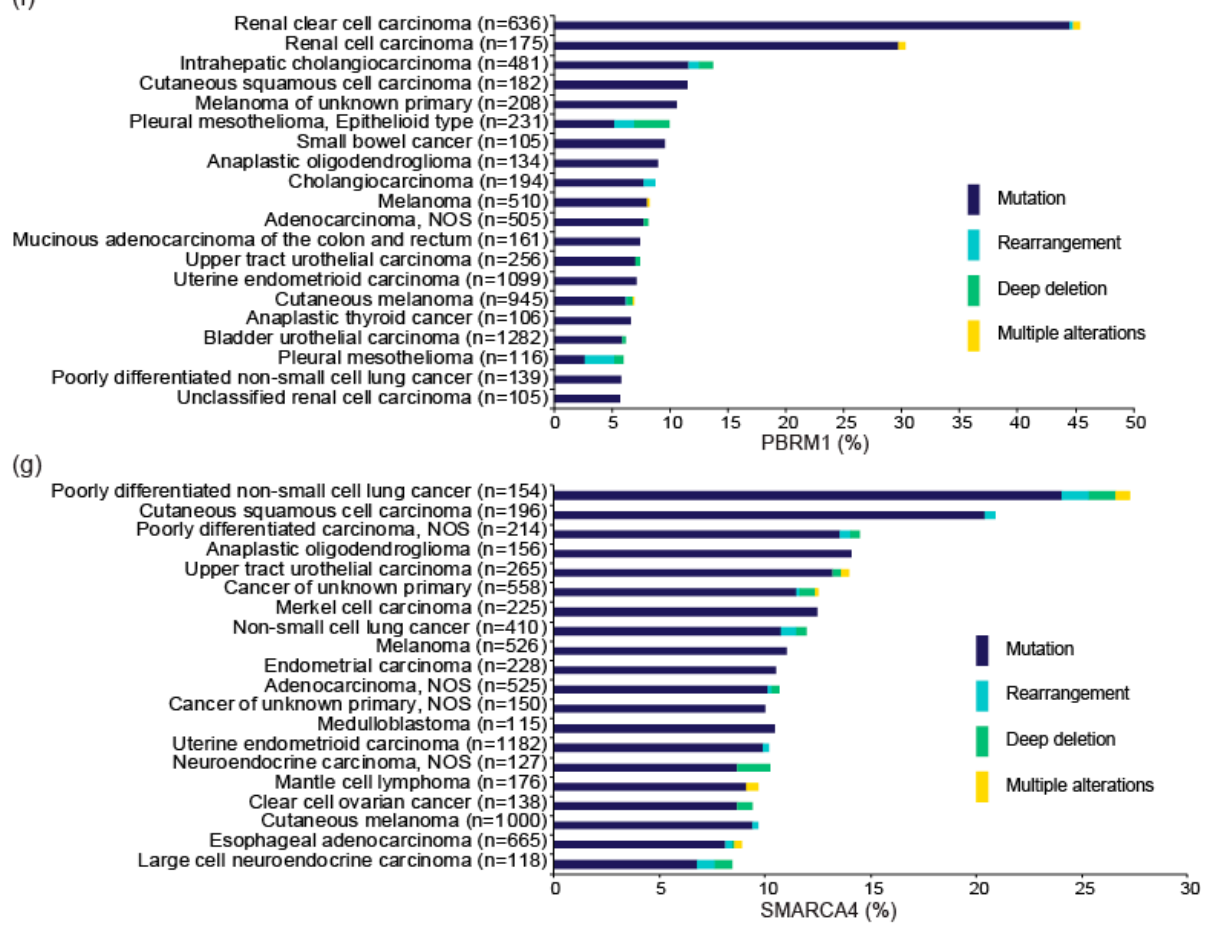

Figure 2. Mutations in genes encoding SWI/SNF chromatin remodeling factors. Mutation frequencies in OCCC (a) and other cancer types (b) in the GENIE Cohort v8.1 are shown. n: number of profiled samples. Top 20 cancer types according to mutation frequency of ARID1A (c), ARID1B (d), ARID2 (e), PBRM1 (f), and SMARCA (g) are shown. Cancer types detailed with >100 cases in the GENIE Cohort v8.1 are also shown. The four types of gene alteration are color-coded. 
$A R I D 1 A$ is also frequently mutated in uterine endometrial and endometrioid ovarian cancers; therefore, aberrations in this gene are likely to be frequently involved in malignancies of the female genital tract. In addition, SMARCA4, which is frequently mutated in poorly differentiated non-small cell lung cancer (Figure $2 \mathrm{~g}$ ), is also mutated in a subset (about 10\%) of OCCC. SMARCA4 mutations are also extremely frequent (almost ubiquitous) in small cell carcinoma of the ovary of hypercalcemic type (SCCOHT), occurring in about $98 \%$ of such cases. Somatic and germline SMARCA4 mutations drive development of this disease [30,31]. Therefore, deficiency of SWI/SNF chromatin remodeling contributes to ovarian cancer development in several ways.

Figure 3a summarizes the frequencies of ARID1A mutations and loss of BAF250A/ ARID1A protein expression in OCCC in studies to date [12,13,32-37]. In particular, many immunohistochemical studies to examine loss of BAF250A expression in OCCC tissues have been performed [38-40]. Loss of BAF250A, reflected by lack of nuclear staining for this protein, is observed frequently in OCCC cells. The frequency of ARID1A mutations in OCCC is $\sim 60 \%$ in the US, Canada, and Japan, and $40 \%$ in Australia, and the frequencies of loss of BAF250A expression are equal to or a bit lower than the mutation frequencies. These data indicate that a significant fraction of ARID1A mutations is associated with loss of expression of the gene product. Consistent with this, ARID1A mutations observed in OCCC in the Project GENIE Cohort consist mostly $(>90 \%)$ of truncating mutations (Figure 3b, upper) that are dispersed throughout the coding sequence. ARID1A contains two DNA-binding domains, the ARID domain (AT-rich interacting domain) and the C-terminal domain, which plays a critical role in promoting transcription [41]. Most truncation mutations remove the C-terminal domain, whereas missense mutations affecting the glycine at position 2087 decrease the stability of the ARID1A protein [42]. This predominance of truncation mutations and missense mutations at Gly2087 is also observed in a wide range of cancers other than OCCC. Thus, deleterious ARID1A mutations are a common feature of OCCC and other cancers.

The pathogenic roles of ARID1A deficiency during OCCC development were recently elucidated. Indeed, somatic mutations in the ARID1A and PIK3CA genes are detected in benign endometriosis $[29,43]$. Concordantly, a study using a mouse model demonstrated that ARID1A deficiency, in concert with an oncogenic PIK3CA mutation, promotes OCCC formation in vivo by enhancing inflammatory cytokine signaling [44]. In addition, another study demonstrated that alterations in both the ARID1A and PI3-Kinase (PI3K) pathways promote epithelial trans-differentiation and invasion [45]. The epigenetic role of ARID1A was also revealed in a pre-OCCC model system: ARID1A prevents superenhancer hyperactivation, which leads to enhanced migratory properties exhibited by pre-OCCC cells [46]. In addition, a common role shared by ARID1A and another SWI/SNF factor, SMARCA4/BRG1, maintains the integrity of the endometrial epithelium [47]. Thus, ARID1A and other SWI/SNF factors are likely to function epigenetically as a tumor suppressor for the development of ovarian cancer.

(a)

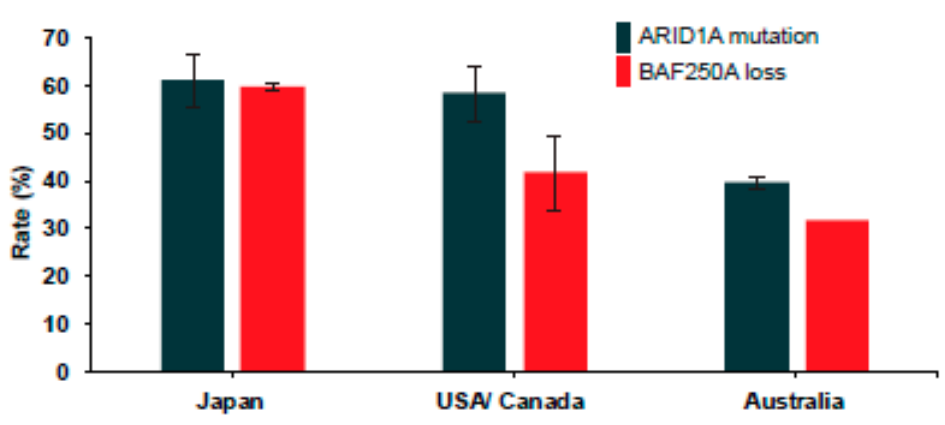

Figure 3. Cont. 


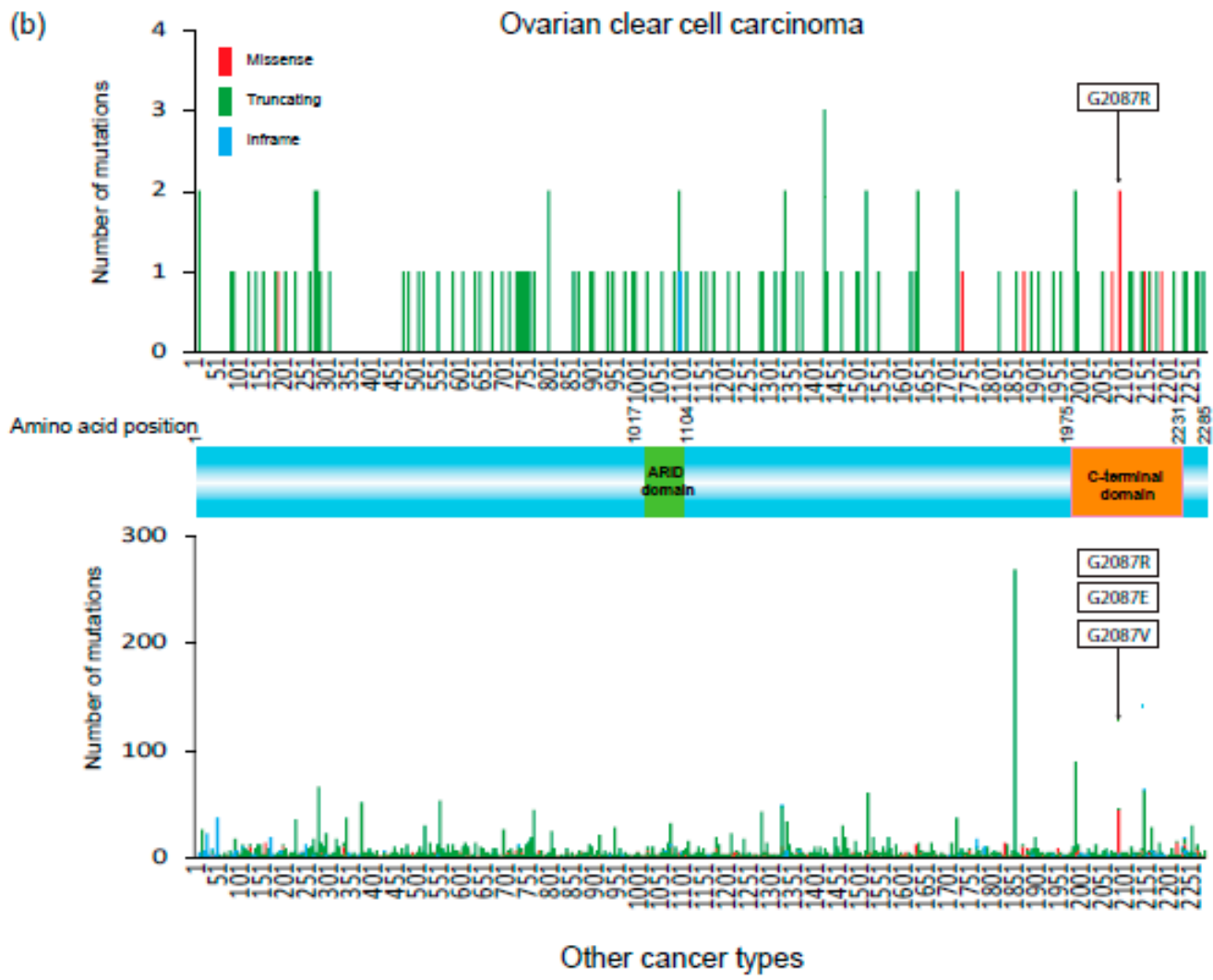

Figure 3. ARID1A alterations in OCCC. (a) Frequency of ARID1A mutations and loss of BAF250A/ARID1A protein expression in OCCC in Japan, the US, Canada, and Australia. Frequencies in published results [12,13,32-37] are expressed as the mean \pm standard error. (b) Distribution of ARID1A mutants on the wild-type BAF250A/ARID1A protein sequence (GENIE Cohort v8.1). Upper and lower panels show mutations in OCCC (127 mutations) and other cancers, respectively. Mutations are colored by the type of mutations: missense, truncating (7114 mutations: nonsense, frameshift, and splice site mutations), or in-frame. Deleterious missense mutations at codon 2087 are indicated by boxes.

\section{Therapeutic Strategies for OCCC Based on the Phenotypes of ARID1A Deficiency}

The BAF250A/ARID1A protein functions as a regulatory subunit of the SWI/SNF complex, which regulates multiple cellular processes, including transcription and DNA repair. Therefore, it is possible that cancer cells deficient in ARID1A or other SWI/SNF subunits share properties that are absent from noncancerous cells, and that some of those properties create vulnerabilities [10]. Targeting this vulnerability with anti-cancer drugs represents a potentially effective strategy for treating OCCC. Indeed, several studies to date have proposed such approaches, which are categorized into three groups.

\subsection{Prioritizing Gemcitabine-Based Chemotherapeutic Regimens}

Gemcitabine is a deoxycytidine analogue that inhibits ribonucleoside reductase, resulting in depletion of deoxyribonucleotide pools required for DNA synthesis. Gemcitabine is often used in late lines of treatment for ovarian cancer after platinum-resistant recurrence; however, retrospective studies have shown that gemcitabine is especially effective against OCCC [48-50]. Notably in this regard, we demonstrated that knockout of ARID1A increases the sensitivity of OCCC cells to gemcitabine by approximately 100-fold. Consistent with this, ARID1A-deficient cases of OCCC exhibited significantly longer progression-free survival after gemcitabine treatment than ARID1A-proficient cases [51]. The mechanisms underlying this phenomenon are unknown, but it seems likely that patients with ARID1Adeficient OCCC would benefit from treatment with gemcitabine. 


\subsection{Synthetic Lethal Therapy Targeting Vulnerabilities Conferred by ARID1A Deficiency}

Loss-of-function mutations in the BRCA1 and BRCA2 genes have opened the prospect of developing new synthetic lethal therapies based on PARP inhibitors [52]. However, these therapeutic options are limited in OCCC due to the low frequency of $B R C A 1 / B R C A 2$ mutations in these cancers [53]. Consequently, a great deal of attention has been paid to synthetic lethal therapies that target vulnerabilities conferred by ARID1A deficiency. Like the BRCA1 and BRCA2 proteins, BAF250A/ARID1A promotes homologous recombinationmediated repair of DNA double-strand breaks, suggesting that PARP inhibition might be therapeutically effective [14]. Clinical trials of the PARP inhibitors olaparib and niraparib, using ARID1A deficiency as a biomarker, are underway in ovarian and other cancers (NCT04065269, NCT04042831, NCT03207347) (Table 1).

The SWI/SNF complex and another chromatin remodeling complex, polycomb repressive complex 2 (PRC2), work antagonistically during transcription. EZH2 serves as the catalytic subunit in the PRC2 complex and mediates gene silencing. Dysfunction of the SWI/SNF complex due to ARID1A-deficiency leads to predominance of PRC2 activity in cancer cells [54,55]. In line with this, the therapeutic potential of EZH2 inhibitors against ARID1A-deficient cancers has been demonstrated [56]. The efficacy of an EZH2 inhibitor tazemetostat [57], which has been approved by the US FDA for the treatment of epithelioid sarcoma, is being tested against ovarian endometrial cancer, ovarian clear cell carcinoma, and endometrial cancer in an ongoing clinical trial (NCT03348631), again using ARID1A deficiency as a biomarker. In a Phase II clinical trial, tazemetostat exhibited an objective response rate of $69 \%$ in follicular lymphoma with activating EZH2 mutations; severe adverse events, such as thrombocytopenia, neutropenia, and anemia, were observed only in a small subset of cases [58]. Therefore, tazemetostat is a promising drug for the treatment of ARID1A-deficient OCCC.

In addition, several other genes, including $A T R, H D A C 2, B R D 2$, and $H D A C 6$, have synthetic lethal relationships with ARID1A [59-62]. Inhibitors of the products of these genes have already been approved for several non-ovarian cancers. For instance, multiple HDAC inhibitors have been approved by the FDA for cutaneous/peripheral T-cell lymphoma and multiple myeloma $[63,64]$. Among them, vorinostat, romidepsin, and belinostat have been investigated in clinical trials for epithelial ovarian cancer (Table 2). Trials of the vorinostat treatment combined with cytotoxic drugs were discontinued due to severe hematologic toxicity and gastrointestinal toxicity $[65,66]$. In a Phase II trial of recurrent platinum-refractory ovarian cancer, single treatment with vorinostat did not yield an evident response, although the drug was well tolerated [67]. Belinostat was also well tolerated in a combination regimen with paclitaxel and carboplatin [68]. The therapeutic efficacy of HDAC inhibitors against OCCC with ARID1A deficiency should be investigated in the future.

We recently reported that ARID1A deficiency is associated with reduced metabolism of the antioxidant glutathione (GSH) [15]; consistent with this, ARID1A-deficient OCCC cells are sensitive to GSH inhibitors such as the investigational drugs APR-246 and buthionine sulfoximine (BSO). APR-246 was originally developed as a reactivator of mutant TP53 protein and is currently in Phase Ib/II clinical trials for hematological tumors (NCT04214860, NCT03931291) [69]. BSO was previously examined in a Phase I trial for melanoma and neuroblastoma (NCT00002730, NCT00005835), but it is not involved in any active clinical trials at the moment. Clinical trials of these inhibitors for OCCC would be worth undertaking. 
Table 1. ARID1A-target therapy.

\begin{tabular}{|c|c|c|c|c|}
\hline \multirow{2}{*}{ Theraputic Targets } & \multirow{2}{*}{ Drug } & \multicolumn{2}{|c|}{ Clinical Trial Biomarker } & \multirow{2}{*}{ Development Grade } \\
\hline & & ARID1A Mutation & BAF250A Loss & \\
\hline \multicolumn{5}{|c|}{ Conventional chemothrapy } \\
\hline Ribonucleoside reductase & Gemcitabine & - & - & A \\
\hline \multicolumn{5}{|l|}{ Synthetic lethal therapy } \\
\hline GSH & APR-246 & - & - & $\mathrm{D}$ \\
\hline GCLC & Buthionine sulfoximine (BSO) & - & & $\mathrm{D}$ \\
\hline \multirow{2}{*}{ Induced ROS accumulation } & Elesclomol & - & - & $\mathrm{D}$ \\
\hline & GSK2816126 & - & - & $\mathrm{D}$ \\
\hline \multirow{3}{*}{ EZH2 } & Tazemetostat & NCT03348631 & NCT03348631 & $\mathrm{B}, \mathrm{C}$ \\
\hline & CPI-1205 & - & - & $\mathrm{D}$ \\
\hline & SHR2554 & - & - & $\mathrm{D}$ \\
\hline HDAC2 & Vorinostat (SAHA) & - & - & $\mathrm{B}$ \\
\hline HDAC6 & Ricolinostat & - & - & $\mathrm{D}$ \\
\hline ARID1B & - & - & - & - \\
\hline BRD2 & I-BET-762 & - & - & $\mathrm{D}$ \\
\hline \multirow{2}{*}{ PARP } & Olaparib & NCT04042831 & NCT04065269 & $A, C$ \\
\hline & Niraparib & NCT03207347 & - & A, C \\
\hline ATR & Berzosertib & - & - & $\mathrm{D}$ \\
\hline YES1 & Dasatinib & $\begin{array}{l}\text { NCT02059265, } \\
\text { NCT04284202 }\end{array}$ & NCT02059265 & $\mathrm{C}$ \\
\hline \multicolumn{5}{|l|}{ Immunotherapy } \\
\hline \multirow{2}{*}{ PD-1 } & Nivolumab & - & - & B \\
\hline & Pembrolizumab & NCT04611139 & - & B \\
\hline
\end{tabular}

A: FDA-approved for ovarian cancer, B: FDA-approved for other cancer, C: Clinical trial underway for ovarian cancer using ARID1A as a biomarker, D: Clinical trials underway for ovarian cancer or other cancer without using ARID1A as a biomarker. Information on the clinical trials can be obtained at https:/ / www.clinicaltrials.gov / (accessed on 19 November 2020).

Table 2. Clinical trials of FDA approved HDAC inhibitors in ovarian cancer.

\begin{tabular}{|c|c|c|c|c|c|c|}
\hline $\begin{array}{l}\text { Theraputic } \\
\text { Targets }\end{array}$ & Drug & $\begin{array}{l}\text { Clinical } \\
\text { Phase }\end{array}$ & $\begin{array}{l}\text { Combination } \\
\text { Regimens }\end{array}$ & Cancer Type & $\begin{array}{l}\text { ClinicalTrials.gov } \\
\text { Identifier }\end{array}$ & $\begin{array}{c}\text { Recruitment } \\
\text { Status }\end{array}$ \\
\hline \multirow{12}{*}{ HDAC } & \multirow{5}{*}{ Volinostat } & $\mathrm{I} / \mathrm{II}$ & Pac, Carbo & Recurrent EOC & NCT00772798 & Unknown \\
\hline & & $\mathrm{I} / \mathrm{II}$ & Pac, Carbo & Stage III/IV EOC & NCT00976183 & $\begin{array}{l}\text { Terminated } \\
\text { (toxicities) }\end{array}$ \\
\hline & & $\mathrm{Ib} / \mathrm{II}$ & Gem, Carbo & Platinum-sensitive recurrent EOC & NCT00910000 & $\begin{array}{l}\text { Terminated } \\
\text { (toxicities) }\end{array}$ \\
\hline & & II & - & Recurrent EOC & NCT00132067 & Completed \\
\hline & & I & - & Advanced ST and HM & NCT00045006 & Completed \\
\hline & Romidepsin & II & - & Recurrent EOC & NCT00091195 & Terminated \\
\hline & \multirow{6}{*}{ Belinostat } & $\mathrm{I} / \mathrm{Ib}$ & Ribociclib & Metastatic TNBC and recurrent EOC & NCT04315233 & Recruiting \\
\hline & & II & Pac, Carbo & Recurrent EOC and BC & NCT00421889 & Completed \\
\hline & & II & - & Recurrent EOC and BLM & NCT00301756 & Completed \\
\hline & & II & Carbo & Recurrent EOC & NCT00993616 & Completed \\
\hline & & $\mathrm{I}$ & - & Advanced ST & NCT00413075 & Completed \\
\hline & & I & 5-FU & Advanced ST & NCT00413322 & Completed \\
\hline
\end{tabular}

EOC: Epitherial ovarian cancer, BLM: Borderline ovarian tumor, ST:Solid tumors, HM: Hematologic malignancies; TNBC: Triple negative breast cancer, BC: Bladder cancer; Pac: Paclitaxel, Carbo: Carboplatin, Gem: Gemcitabine, 5-FU: 5-Fluoruracil.

\subsection{Immune Checkpoint Blockade Therapy Exploiting the High Mutational Burden of ARID1A-Deficient Tumors}

Tumors with the deficient mismatch repair (dMMR) phenotype respond well to immune checkpoint blockade therapy, as these tumors express many neo-antigens associated with high mutational burden [70]. BAF250A/ARID1A protein interacts with the MMR protein MSH2 and promotes MMR. Therefore, ARID1A deficiency might be an indicator of the dMMR phenotype, which is linked to the efficacy of immune checkpoint blockade therapy. The dMMR phenotype is observed in 3-14\% of OCCC cases [71-75], whereas the relationship between ARID1A deficiency and dMMR is unclear. The number of OCCC patients enrolled in previous clinical trials of immune checkpoint inhibitors is very limited; 
therefore, the efficacy of therapeutic agents against OCCC remains unclear [76-78]. Notably, a clinical trial of the immune checkpoint inhibitor pembrolizumab, using ARID1A deficiency as a biomarker, is currently underway (NCT0461139); therefore, the proof of concept (POC) will be clarified in vivo in the near future.

\section{Future Directions}

At present, precision medicine for OCCC using SWI/SNF chromatin remodeling deficiency has not been implemented in daily oncology. Table 1 shows the status of FDA approval and clinical trials for drugs that could be effective against ARID1A-deficient OCCC. Several drugs, such as olaparib, niraparib, tazemetostat, and pembrolizumab, are being tested for their efficacy in clinical trials using ARID1A deficiency as a biomarker. Therefore, the POC obtained in preclinical studies should be validated in vivo in the near future. Other drugs, such as eleclomol, a ROS inducer (NCT00888615) [79], and berzosertib, an ATR inhibitor (NCT02627443), are being tested for efficacy in clinical trials that are enrolling ovarian cancer patients irrespective of ARID1A status. Analysis of the association between clinical response and ARID1A deficiency among studied cases might help to obtain further POC.

The list of target molecules proposed for cancer therapy is expanding day by day. Therefore, it is quite important to consider how discoveries made in preclinical models are translated to clinical trials designed to test whether modulating the activity of specific targets leads to a clinical response [80]. In particular, with respect to OCCC (which is a rare cancer), application of treatment modalities that are either established or are being tested on other major types of cancer would be a way forward. In fact, therapeutic strategies using PI3K-AKT inhibitors combined with HAT and BET (bromodomain and extra-terminal domain) inhibitors are considered strong candidates [81,82].

On the other hand, however, to understand specific/preferential properties of OCCC conferred by gene alterations is also quite important; sensitivity to GSH inhibitors conferred by ARID1A deficiency is much higher in OCCC than other types of cancers, such as gastric cancer $[15,83]$, indicating that biological effects of gene alterations commonly observed in a variety of cancers are, in fact, largely different by cancer types. Therefore, preclinical studies focusing OCCC should also be intensively performed to establish truly feasible and efficient precision medicine of this disease. For this purpose, sharing data and materials of OCCC, which are unfortunately much less than those of many other common cancers, are highly inevitable. To facilitate preclinical studies OCCC, we dare to introduce here that human OCCC cell lines available for research are summarized in a report [84] and their pan-genome/transcriptome profiles are published [85,86]. In addition, patient-derived xenograft models of OCCC, which will give us accurate and specific insights of this disease, are available [87]. We hope that novel concepts of precision OCCC medicine will be produced here and will surely improve the present miserable situation of this disease in the near future.

Author Contributions: The manuscript was written by K.T. and T.K. under the supervision of M.T., D.D.L.B. and A.O. All authors have read and agreed to the published version of the manuscript.

Funding: This research was supported in part by the Japan Agency for Medical Research and Development (AMED) (JP 20ck0106402 to T.K.).

Data Availability Statement: Not applicable.

Conflicts of Interest: The authors declare no conflict of interest.

\section{References}

1. Kobel, M.; Kalloger, S.E.; Huntsman, D.G.; Santos, J.L.; Swenerton, K.D.; Seidman, J.D.; Gilks, C.B.; Cheryl Brown Ovarian Cancer Outcomes Unit of the British Columbia Cancer Agency, V.B.C. Differences in tumor type in low-stage versus high-stage ovarian carcinomas. Int. J. Gynecol. Pathol. 2010, 29, 203-211. [CrossRef] [PubMed]

2. Yamagami, W.; Nagase, S.; Takahashi, F.; Ino, K.; Hachisuga, T.; Aoki, D.; Katabuchi, H. Clinical statistics of gynecologic cancers in Japan. J. Gynecol. Oncol. 2017, 28, e32. [CrossRef] [PubMed] 
3. Anglesio, M.S.; Carey, M.S.; Kobel, M.; Mackay, H.; Huntsman, D.G.; Vancouver Ovarian Clear Cell Symposium, S. Clear cell carcinoma of the ovary: A report from the first Ovarian Clear Cell Symposium, June 24th, 2010. Gynecol. Oncol. 2011, 121, 407-415. [CrossRef] [PubMed]

4. Bookman, M.A.; Okamoto, A.; Stuart, G.; Yanaihara, N.; Aoki, D.; Bacon, M.; Fujiwara, K.; Gonzalez-Martin, A.; Harter, P.; Kim, J.W.; et al. Harmonising clinical trials within the Gynecologic Cancer InterGroup: Consensus and unmet needs from the Fifth Ovarian Cancer Consensus Conference. Ann. Oncol. 2017, 28, viii30-viii35. [CrossRef]

5. Okamoto, A.; Glasspool, R.M.; Mabuchi, S.; Matsumura, N.; Nomura, H.; Itamochi, H.; Takano, M.; Takano, T.; Susumu, N.; Aoki, D.; et al. Gynecologic Cancer InterGroup (GCIG) consensus review for clear cell carcinoma of the ovary. Int. J. Gynecol. Cancer 2014, 24, S20-S25. [CrossRef]

6. Sugiyama, T.; Kamura, T.; Kigawa, J.; Terakawa, N.; Kikuchi, Y.; Kita, T.; Suzuki, M.; Sato, I.; Taguchi, K. Clinical characteristics of clear cell carcinoma of the ovary: A distinct histologic type with poor prognosis and resistance to platinum-based chemotherapy. Cancer 2000, 88, 2584-2589. [CrossRef]

7. Sugiyama, T.; Okamoto, A.; Enomoto, T.; Hamano, T.; Aotani, E.; Terao, Y.; Suzuki, N.; Mikami, M.; Yaegashi, N.; Kato, K.; et al. Randomized Phase III Trial of Irinotecan Plus Cisplatin Compared With Paclitaxel Plus Carboplatin As First-Line Chemotherapy for Ovarian Clear Cell Carcinoma: JGOG3017/GCIG Trial. J. Clin. Oncol. 2016, 34, 2881-2887. [CrossRef]

8. Takahashi, K.; Takenaka, M.; Kawabata, A.; Yanaihara, N.; Okamoto, A. Rethinking of treatment strategies and clinical management in ovarian clear cell carcinoma. Int. J. Clin. Oncol. 2020, 25, 425-431. [CrossRef]

9. Mabuchi, S.; Sugiyama, T.; Kimura, T. Clear cell carcinoma of the ovary: Molecular insights and future therapeutic perspectives. J. Gynecol. Oncol. 2016, 27, e31. [CrossRef]

10. Mittal, P.; Roberts, C.W.M. The SWI/SNF complex in cancer - biology, biomarkers and therapy. Nat. Rev. Clin. Oncol. 2020, 17, 435-448. [CrossRef]

11. McCluggage, W.G.; Stewart, C.J.R. SWI/SNF-deficient malignancies of the female genital tract. Semin. Diagn. Pathol. 2020. [CrossRef]

12. Jones, S.; Wang, T.L.; Shih Ie, M.; Mao, T.L.; Nakayama, K.; Roden, R.; Glas, R.; Slamon, D.; Diaz, L.A., Jr.; Vogelstein, B.; et al. Frequent mutations of chromatin remodeling gene ARID1A in ovarian clear cell carcinoma. Science 2010, 330, 228-231. [CrossRef]

13. Wiegand, K.C.; Shah, S.P.; Al-Agha, O.M.; Zhao, Y.; Tse, K.; Zeng, T.; Senz, J.; McConechy, M.K.; Anglesio, M.S.; Kalloger, S.E.; et al. ARID1A mutations in endometriosis-associated ovarian carcinomas. N. Engl. J. Med. 2010, 363, 1532-1543. [CrossRef]

14. Shen, J.; Peng, Y.; Wei, L.; Zhang, W.; Yang, L.; Lan, L.; Kapoor, P.; Ju, Z.; Mo, Q.; Shih Ie, M.; et al. ARID1A Deficiency Impairs the DNA Damage Checkpoint and Sensitizes Cells to PARP Inhibitors. Cancer Discov. 2015, 5, 752-767. [CrossRef]

15. Ogiwara, H.; Takahashi, K.; Sasaki, M.; Kuroda, T.; Yoshida, H.; Watanabe, R.; Maruyama, A.; Makinoshima, H.; Chiwaki, F.; Sasaki, H.; et al. Targeting the Vulnerability of Glutathione Metabolism in ARID1A-Deficient Cancers. Cancer Cell 2019, 35, 177-190 e178. [CrossRef]

16. Machida, H.; Matsuo, K.; Yamagami, W.; Ebina, Y.; Kobayashi, Y.; Tabata, T.; Kanauchi, M.; Nagase, S.; Enomoto, T.; Mikami, M. Trends and characteristics of epithelial ovarian cancer in Japan between 2002 and 2015: A JSGO-JSOG joint study. Gynecol. Oncol. 2019, 153, 589-596. [CrossRef]

17. Jordan, S.J.; Green, A.C.; Whiteman, D.C.; Webb, P.M.; Australian Ovarian Cancer Study, G. Risk factors for benign, borderline and invasive mucinous ovarian tumors: Epidemiological evidence of a neoplastic continuum? Gynecol. Oncol. 2007, 107, 223-230. [CrossRef]

18. Jordan, S.J.; Green, A.C.; Whiteman, D.C.; Moore, S.P.; Bain, C.J.; Gertig, D.M.; Webb, P.M.; Australian Cancer Study, G.; Australian Ovarian Cancer Study, G. Serous ovarian, fallopian tube and primary peritoneal cancers: A comparative epidemiological analysis. Int. J. Cancer 2008, 122, 1598-1603. [CrossRef]

19. Nagle, C.M.; Olsen, C.M.; Webb, P.M.; Jordan, S.J.; Whiteman, D.C.; Green, A.C.; Australian Cancer Study, G.; Australian Ovarian Cancer Study, G. Endometrioid and clear cell ovarian cancers: A comparative analysis of risk factors. Eur. J. Cancer 2008, 44, 2477-2484. [CrossRef]

20. Shain, A.H.; Pollack, J.R. The spectrum of SWI/SNF mutations, ubiquitous in human cancers. PLoS ONE 2013, 8, e55119. [CrossRef]

21. Kadoch, C.; Hargreaves, D.C.; Hodges, C.; Elias, L.; Ho, L.; Ranish, J.; Crabtree, G.R. Proteomic and bioinformatic analysis of mammalian SWI/SNF complexes identifies extensive roles in human malignancy. Nat. Genet. 2013, 45, 592-601. [CrossRef] [PubMed]

22. Campbell, P.J.; Getz, G.; Korbel, J.O.; Stuart, J.M.; Jennings, J.L.; Stein, L.D.; Perry, M.D.; Nahal-Bose, H.K.; Ouellette, B.F.F.; Li, C.H.; et al. Pan-cancer analysis of whole genomes. Nature 2020, 578, 82. [CrossRef]

23. Zehir, A.; Benayed, R.; Shah, R.H.; Syed, A.; Middha, S.; Kim, H.R.; Srinivasan, P.; Gao, J.J.; Chakravarty, D.; Devlin, S.M.; et al. Mutational landscape of metastatic cancer revealed from prospective clinical sequencing of 10,000 patients. Nature Medicine 2017, 23, 703. [CrossRef]

24. Davoli, T.; Xu, A.W.; Mengwasser, K.E.; Sack, L.M.; Yoon, J.C.; Park, P.J.; Elledge, S.J. Cumulative haploinsufficiency and triplosensitivity drive aneuploidy patterns and shape the cancer genome. Cell 2013, 155, 948-962. [CrossRef] [PubMed]

25. Consortium, A.P.G. AACR Project GENIE: Powering Precision Medicine through an International Consortium. Cancer Discov. 2017, 7, 818-831. [CrossRef] [PubMed] 
26. Oike, T.; Ogiwara, H.; Nakano, T.; Yokota, J.; Kohno, T. Inactivating mutations in SWI/SNF chromatin remodeling genes in human cancer. Jpn. J. Clin. Oncol. 2013, 43, 849-855. [CrossRef] [PubMed]

27. Hermens, M.; van Altena, A.M.; Nieboer, T.E.; Schoot, B.C.; van Vliet, H.; Siebers, A.G.; Bekkers, R.L.M. Incidence of endometrioid and clear-cell ovarian cancer in histological proven endometriosis: The ENOCA population-based cohort study. Am. J. Obstet. Gynecol. 2020, 223, 107.e1-107.e11. [CrossRef]

28. Anglesio, M.S.; Bashashati, A.; Wang, Y.K.; Senz, J.; Ha, G.; Yang, W.; Aniba, M.R.; Prentice, L.M.; Farahani, H.; Li Chang, H.; et al. Multifocal endometriotic lesions associated with cancer are clonal and carry a high mutation burden. J. Pathol. 2015, 236, 201-209. [CrossRef]

29. Anglesio, M.S.; Papadopoulos, N.; Ayhan, A.; Nazeran, T.M.; Noe, M.; Horlings, H.M.; Lum, A.; Jones, S.; Senz, J.; Seckin, T.; et al. Cancer-Associated Mutations in Endometriosis without Cancer. N. Engl. J. Med. 2017, 376, 1835-1848. [CrossRef]

30. Ramos, P.; Karnezis, A.N.; Craig, D.W.; Sekulic, A.; Russell, M.L.; Hendricks, W.P.; Corneveaux, J.J.; Barrett, M.T.; Shumansky, K.; Yang, Y.; et al. Small cell carcinoma of the ovary, hypercalcemic type, displays frequent inactivating germline and somatic mutations in SMARCA4. Nat. Genet. 2014, 46, 427-429. [CrossRef]

31. Witkowski, L.; Carrot-Zhang, J.; Albrecht, S.; Fahiminiya, S.; Hamel, N.; Tomiak, E.; Grynspan, D.; Saloustros, E.; Nadaf, J.; Rivera, B.; et al. Germline and somatic SMARCA4 mutations characterize small cell carcinoma of the ovary, hypercalcemic type. Nat. Genet. 2014, 46, 438-443. [CrossRef]

32. Itamochi, H.; Oishi, T.; Oumi, N.; Takeuchi, S.; Yoshihara, K.; Mikami, M.; Yaegashi, N.; Terao, Y.; Takehara, K.; Ushijima, K.; et al. Whole-genome sequencing revealed novel prognostic biomarkers and promising targets for therapy of ovarian clear cell carcinoma. Br. J. Cancer 2017, 117, 717-724. [CrossRef]

33. Murakami, R.; Matsumura, N.; Brown, J.B.; Higasa, K.; Tsutsumi, T.; Kamada, M.; Abou-Taleb, H.; Hosoe, Y.; Kitamura, S.; Yamaguchi, K.; et al. Exome Sequencing Landscape Analysis in Ovarian Clear Cell Carcinoma Shed Light on Key Chromosomal Regions and Mutation Gene Networks. Am. J. Pathol. 2017, 187, 2246-2258. [CrossRef]

34. Shibuya, Y.; Tokunaga, H.; Saito, S.; Shimokawa, K.; Katsuoka, F.; Bin, L.; Kojima, K.; Nagasaki, M.; Yamamoto, M.; Yaegashi, N.; et al. Identification of somatic genetic alterations in ovarian clear cell carcinoma with next generation sequencing. Genes Chromosomes Cancer 2018, 57, 51-60. [CrossRef]

35. Takenaka, M.; Kobel, M.; Garsed, D.W.; Fereday, S.; Pandey, A.; Etemadmoghadam, D.; Hendley, J.; Kawabata, A.; Noguchi, D.; Yanaihara, N.; et al. Survival Following Chemotherapy in Ovarian Clear Cell Carcinoma Is Not Associated with Pathological Misclassification of Tumor Histotype. Clin. Cancer Res. 2019, 25, 3962-3973. [CrossRef]

36. Maeda, D.; Mao, T.L.; Fukayama, M.; Nakagawa, S.; Yano, T.; Taketani, Y.; Shih Ie, M. Clinicopathological significance of loss of ARID1A immunoreactivity in ovarian clear cell carcinoma. Int. J. Mol. Sci. 2010, 11, 5120-5128. [CrossRef]

37. Lheureux, S.; Tinker, A.; Clarke, B.; Ghatage, P.; Welch, S.; Weberpals, J.I.; Dhani, N.C.; Butler, M.O.; Tonkin, K.; Tan, Q.; et al. A Clinical and Molecular Phase II Trial of Oral ENMD-2076 in Ovarian Clear Cell Carcinoma (OCCC): A Study of the Princess Margaret Phase II Consortium. Clin. Cancer Res. 2018, 24, 6168-6174. [CrossRef]

38. Bennett, J.A.; Safdar, N.; Segal, J.P.; Lastra, R.R.; Oliva, E. Evaluation of SWI/SNF Protein Expression by Immunohistochemistry in Ovarian Clear Cell Carcinoma. Int. J. Gynecol. Pathol. 2021, 40, 156-164. [CrossRef]

39. Barreta, A.; Sarian, L.O.; Ferracini, A.C.; Costa, L.B.E.; Mazzola, P.G.; de Angelo Andrade, L.; Derchain, S. Immunohistochemistry expression of targeted therapies biomarkers in ovarian clear cell and endometrioid carcinomas (type I) and endometriosis. Hum. Pathol. 2019, 85, 72-81. [CrossRef]

40. Abou-Taleb, H.; Yamaguchi, K.; Matsumura, N.; Murakami, R.; Nakai, H.; Higasa, K.; Amano, Y.; Abiko, K.; Yoshioka, Y.; Hamanishi, J.; et al. Comprehensive assessment of the expression of the SWI/SNF complex defines two distinct prognostic subtypes of ovarian clear cell carcinoma. Oncotarget 2016, 7, 54758-54770. [CrossRef]

41. Inoue, H.; Furukawa, T.; Giannakopoulos, S.; Zhou, S.; King, D.S.; Tanese, N. Largest subunits of the human SWI/SNF chromatinremodeling complex promote transcriptional activation by steroid hormone receptors. J. Biol. Chem. 2002, 277, 41674-41685. [CrossRef]

42. Mashtalir, N.; D’Avino, A.R.; Michel, B.C.; Luo, J.; Pan, J.; Otto, J.E.; Zullow, H.J.; McKenzie, Z.M.; Kubiak, R.L.; St Pierre, R.; et al. Modular Organization and Assembly of SWI/SNF Family Chromatin Remodeling Complexes. Cell 2018, 175, 1272-1288 e1220. [CrossRef]

43. Suda, K.; Nakaoka, H.; Yoshihara, K.; Ishiguro, T.; Tamura, R.; Mori, Y.; Yamawaki, K.; Adachi, S.; Takahashi, T.; Kase, H.; et al. Clonal Expansion and Diversification of Cancer-Associated Mutations in Endometriosis and Normal Endometrium. Cell Rep. 2018, 24, 1777-1789. [CrossRef]

44. Chandler, R.L.; Damrauer, J.S.; Raab, J.R.; Schisler, J.C.; Wilkerson, M.D.; Didion, J.P.; Starmer, J.; Serber, D.; Yee, D.; Xiong, J.; et al. Coexistent ARID1A-PIK3CA mutations promote ovarian clear-cell tumorigenesis through pro-tumorigenic inflammatory cytokine signalling. Nat. Commun. 2015, 6, 6118. [CrossRef]

45. Wilson, M.R.; Reske, J.J.; Holladay, J.; Wilber, G.E.; Rhodes, M.; Koeman, J.; Adams, M.; Johnson, B.; Su, R.W.; Joshi, N.R.; et al. ARID1A and PI3-kinase pathway mutations in the endometrium drive epithelial transdifferentiation and collective invasion. Nat. Commun. 2019, 10, 3554. [CrossRef]

46. Wilson, M.R.; Reske, J.J.; Holladay, J.; Neupane, S.; Ngo, J.; Cuthrell, N.; Wegener, M.; Rhodes, M.; Adams, M.; Sheridan, R.; et al. ARID1A Mutations Promote P300-Dependent Endometrial Invasion through Super-Enhancer Hyperacetylation. Cell Rep. 2020, 33, 108366. [CrossRef] 
47. Reske, J.J.; Wilson, M.R.; Holladay, J.; Wegener, M.; Adams, M.; Chandler, R.L. SWI/SNF inactivation in the endometrial epithelium leads to loss of epithelial integrity. Hum. Mol. Genet. 2020, 29, 3412-3430. [CrossRef]

48. Crotzer, D.R.; Sun, C.C.; Coleman, R.L.; Wolf, J.K.; Levenback, C.F.; Gershenson, D.M. Lack of effective systemic therapy for recurrent clear cell carcinoma of the ovary. Gynecol. Oncol. 2007, 105, 404-408. [CrossRef]

49. Ferrandina, G.; Legge, F.; Mey, V.; Nannizzi, S.; Ricciardi, S.; Petrillo, M.; Corrado, G.; Scambia, G. A case of drug resistant clear cell ovarian cancer showing responsiveness to gemcitabine at first administration and at re-challenge. Cancer Chemother. Pharmacol. 2007, 60, 459-461. [CrossRef]

50. Yoshino, K.; Enomoto, T.; Fujita, M.; Ueda, Y.; Kimura, T.; Kobayashi, E.; Tsutsui, T.; Kimura, T. Salvage chemotherapy for recurrent or persistent clear cell carcinoma of the ovary: A single-institution experience for a series of 20 patients. Int. J. Clin. Oncol. 2013, 18, 148-153. [CrossRef]

51. Kuroda, T.; Ogiwara, H.; Sasaki, M.; Takahashi, K.; Yoshida, H.; Kiyokawa, T.; Sudo, K.; Tamura, K.; Kato, T.; Okamoto, A.; et al. Therapeutic preferability of gemcitabine for ARID1A-deficient ovarian clear cell carcinoma. Gynecol. Oncol. 2019, 155, 489-498. [CrossRef] [PubMed]

52. Ledermann, J.; Harter, P.; Gourley, C.; Friedlander, M.; Vergote, I.; Rustin, G.; Scott, C.L.; Meier, W.; Shapira-Frommer, R.; Safra, T.; et al. Olaparib maintenance therapy in patients with platinum-sensitive relapsed serous ovarian cancer: A preplanned retrospective analysis of outcomes by BRCA status in a randomised phase 2 trial. Lancet Oncol. 2014, 15, 852-861. [CrossRef]

53. Jang, J.Y.A.; Yanaihara, N.; Pujade-Lauraine, E.; Mikami, Y.; Oda, K.; Bookman, M.; Ledermann, J.; Shimada, M.; Kiyokawa, T.; Kim, B.G.; et al. Update on rare epithelial ovarian cancers: Based on the Rare Ovarian Tumors Young Investigator Conference. J. Gynecol. Oncol. 2017, 28, e54. [CrossRef] [PubMed]

54. Wilson, B.G.; Wang, X.; Shen, X.; McKenna, E.S.; Lemieux, M.E.; Cho, Y.J.; Koellhoffer, E.C.; Pomeroy, S.L.; Orkin, S.H.; Roberts, C.W. Epigenetic antagonism between polycomb and SWI/SNF complexes during oncogenic transformation. Cancer Cell 2010, 18, 316-328. [CrossRef]

55. Poynter, S.T.; Kadoch, C. Polycomb and trithorax opposition in development and disease. Wiley Interdiscip Rev. Dev. Biol. 2016, 5, 659-688. [CrossRef]

56. Bitler, B.G.; Aird, K.M.; Garipov, A.; Li, H.; Amatangelo, M.; Kossenkov, A.V.; Schultz, D.C.; Liu, Q.; Shih Ie, M.; Conejo-Garcia, J.R.; et al. Synthetic lethality by targeting EZH2 methyltransferase activity in ARID1A-mutated cancers. Nat. Med. 2015, 21, 231-238. [CrossRef]

57. Hoy, S.M. Tazemetostat: First Approval. Drugs 2020, 80, 513-521. [CrossRef]

58. Morschhauser, F.; Tilly, H.; Chaidos, A.; McKay, P.; Phillips, T.; Assouline, S.; Batlevi, C.L.; Campbell, P.; Ribrag, V.; Damaj, G.L.; et al. Tazemetostat for patients with relapsed or refractory follicular lymphoma: An open-label, single-arm, multicentre, phase 2 trial. The Lancet Oncology 2020, 21, 1433-1442. [CrossRef]

59. Bitler, B.G.; Wu, S.; Park, P.H.; Hai, Y.; Aird, K.M.; Wang, Y.; Zhai, Y.; Kossenkov, A.V.; Vara-Ailor, A.; Rauscher, F.J., III; et al. ARID1A-mutated ovarian cancers depend on HDAC6 activity. Nat. Cell Biol. 2017, 19, 962-973. [CrossRef]

60. Williamson, C.T.; Miller, R.; Pemberton, H.N.; Jones, S.E.; Campbell, J.; Konde, A.; Badham, N.; Rafiq, R.; Brough, R.; Gulati, A.; et al. ATR inhibitors as a synthetic lethal therapy for tumours deficient in ARID1A. Nat. Commun. 2016, 7, 13837. [CrossRef]

61. Fukumoto, T.; Zhang, R.; Bitler, B.G. Epigenetic inhibitors for the precision treatment of ARID1A-mutant ovarian cancers: What are the next steps? Expert Rev. Precis Med. Drug Dev. 2018, 3, 233-236. [CrossRef] [PubMed]

62. Berns, K.; Caumanns, J.J.; Hijmans, E.M.; Gennissen, A.M.C.; Severson, T.M.; Evers, B.; Wisman, G.B.A.; Jan Meersma, G.; Lieftink, C.; Beijersbergen, R.L.; et al. ARID1A mutation sensitizes most ovarian clear cell carcinomas to BET inhibitors. Oncogene 2018, 37, 4611-4625. [CrossRef] [PubMed]

63. Cappellacci, L.; Perinelli, D.R.; Maggi, F.; Grifantini, M.; Petrelli, R. Recent Progress in Histone Deacetylase Inhibitors as Anticancer Agents. Curr Med. Chem. 2020, 27, 2449-2493. [CrossRef] [PubMed]

64. Li, T.; Zhang, C.; Hassan, S.; Liu, X.; Song, F.; Chen, K.; Zhang, W.; Yang, J. Histone deacetylase 6 in cancer. J. Hematol Oncol. 2018, 11, 111. [CrossRef]

65. Matulonis, U.; Berlin, S.; Lee, H.; Whalen, C.; Obermayer, E.; Penson, R.; Liu, J.; Campos, S.; Krasner, C.; Horowitz, N. Phase I study of combination of vorinostat, carboplatin, and gemcitabine in women with recurrent, platinum-sensitive epithelial ovarian, fallopian tube, or peritoneal cancer. Cancer Chemother. Pharmacol. 2015, 76, 417-423. [CrossRef]

66. Mendivil, A.A.; Micha, J.P.; Brown, J.V., 3rd; Rettenmaier, M.A.; Abaid, L.N.; Lopez, K.L.; Goldstein, B.H. Increased incidence of severe gastrointestinal events with first-line paclitaxel, carboplatin, and vorinostat chemotherapy for advanced-stage epithelial ovarian, primary peritoneal, and fallopian tube cancer. Int. J. Gynecol. Cancer 2013, 23, 533-539. [CrossRef]

67. Modesitt, S.C.; Sill, M.; Hoffman, J.S.; Bender, D.P.; Gynecologic Oncology, G. A phase II study of vorinostat in the treatment of persistent or recurrent epithelial ovarian or primary peritoneal carcinoma: A Gynecologic Oncology Group study. Gynecol. Oncol. 2008, 109, 182-186. [CrossRef]

68. Dizon, D.S.; Damstrup, L.; Finkler, N.J.; Lassen, U.; Celano, P.; Glasspool, R.; Crowley, E.; Lichenstein, H.S.; Knoblach, P.; Penson, R.T. Phase II activity of belinostat (PXD-101), carboplatin, and paclitaxel in women with previously treated ovarian cancer. Int. J. Gynecol. Cancer 2012, 22, 979-986. [CrossRef]

69. Lambert, J.M.; Gorzov, P.; Veprintsev, D.B.; Soderqvist, M.; Segerback, D.; Bergman, J.; Fersht, A.R.; Hainaut, P.; Wiman, K.G.; Bykov, V.J. PRIMA-1 reactivates mutant p53 by covalent binding to the core domain. Cancer Cell 2009, 15, 376-388. [CrossRef] 
70. Shen, J.; Ju, Z.; Zhao, W.; Wang, L.; Peng, Y.; Ge, Z.; Nagel, Z.D.; Zou, J.; Wang, C.; Kapoor, P.; et al. ARID1A deficiency promotes mutability and potentiates therapeutic antitumor immunity unleashed by immune checkpoint blockade. Nat. Med. 2018, 24, 556-562. [CrossRef]

71. Cai, K.Q.; Albarracin, C.; Rosen, D.; Zhong, R.; Zheng, W.; Luthra, R.; Broaddus, R.; Liu, J. Microsatellite instability and alteration of the expression of hMLH1 and hMSH2 in ovarian clear cell carcinoma. Hum. Pathol. 2004, 35, 552-559. [CrossRef]

72. Bennett, J.A.; Morales-Oyarvide, V.; Campbell, S.; Longacre, T.A.; Oliva, E. Mismatch Repair Protein Expression in Clear Cell Carcinoma of the Ovary: Incidence and Morphologic Associations in 109 Cases. Am. J. Surg. Pathol. 2016, 40, 656-663. [CrossRef]

73. Willis, B.C.; Sloan, E.A.; Atkins, K.A.; Stoler, M.H.; Mills, A.M. Mismatch repair status and PD-L1 expression in clear cell carcinomas of the ovary and endometrium. Mod. Pathol. 2017, 30, 1622-1632. [CrossRef]

74. Howitt, B.E.; Strickland, K.C.; Sholl, L.M.; Rodig, S.; Ritterhouse, L.L.; Chowdhury, D.; D'Andrea, A.D.; Matulonis, U.A.; Konstantinopoulos, P.A. Clear cell ovarian cancers with microsatellite instability: A unique subset of ovarian cancers with increased tumor-infiltrating lymphocytes and PD-1/PD-L1 expression. Oncoimmunology 2017, 6, e1277308. [CrossRef]

75. Lin, S.Y.; Hang, J.F.; Lin, Y.Y.; Lai, C.R.; Ho, H.L.; Chou, T.Y. Diffuse Intratumoral Stromal Inflammation in Ovarian Clear Cell Carcinoma is Associated with Loss of Mismatch Repair Protein and High PD-L1 Expression. Int. J. Gynecol. Pathol. 2021, 40, 148-155. [CrossRef]

76. Hamanishi, J.; Mandai, M.; Ikeda, T.; Minami, M.; Kawaguchi, A.; Murayama, T.; Kanai, M.; Mori, Y.; Matsumoto, S.; Chikuma, S.; et al. Safety and Antitumor Activity of Anti-PD-1 Antibody, Nivolumab, in Patients with Platinum-Resistant Ovarian Cancer. J. Clin. Oncol. 2015, 33, 4015-4022. [CrossRef]

77. Disis, M.L.; Taylor, M.H.; Kelly, K.; Beck, J.T.; Gordon, M.; Moore, K.M.; Patel, M.R.; Chaves, J.; Park, H.; Mita, A.C.; et al. Efficacy and Safety of Avelumab for Patients With Recurrent or Refractory Ovarian Cancer: Phase 1b Results From the JAVELIN Solid Tumor Trial. JAMA Oncol. 2019, 5, 393-401. [CrossRef]

78. Matulonis, U.A.; Shapira-Frommer, R.; Santin, A.D.; Lisyanskaya, A.S.; Pignata, S.; Vergote, I.; Raspagliesi, F.; Sonke, G.S.; Birrer, M.; Provencher, D.M.; et al. Antitumor activity and safety of pembrolizumab in patients with advanced recurrent ovarian cancer: Results from the phase II KEYNOTE-100 study. Ann. Oncol. 2019, 30, 1080-1087. [CrossRef]

79. Kwan, S.Y.; Cheng, X.; Tsang, Y.T.; Choi, J.S.; Kwan, S.Y.; Izaguirre, D.I.; Kwan, H.S.; Gershenson, D.M.; Wong, K.K. Loss of ARID1A expression leads to sensitivity to ROS-inducing agent elesclomol in gynecologic cancer cells. Oncotarget 2016, 7, 56933-56943. [CrossRef]

80. Hahn, W.C.; Bader, J.S.; Braun, T.P.; Califano, A.; Clemons, P.A.; Druker, B.J.; Ewald, A.J.; Fu, H.; Jagu, S.; Kemp, C.J.; et al. An expanded universe of cancer targets. Cell 2021, 184, 1142-1155. [CrossRef]

81. Wu, D.; Yan, Y.; Wei, T.; Ye, Z.; Xiao, Y.; Pan, Y.; Orme, J.J.; Wang, D.; Wang, L.; Ren, S.; et al. An acetyl-histone vulnerability in PI3K/AKT inhibition-resistant cancers is targetable by both BET and HDAC inhibitors. Cell reports 2021, 34, 108744. [CrossRef]

82. Shigeta, S.; Lui, G.Y.L.; Shaw, R.; Moser, R.; Gurley, K.E.; Durenberger, G.; Rosati, R.; Diaz, R.L.; Ince, T.A.; Swisher, E.M.; et al. Targeting BET Proteins BRD2 and BRD3 in Combination with PI3K-AKT Inhibition as a Therapeutic Strategy for Ovarian Clear Cell Carcinoma. Mol. Cancer Ther 2021. [CrossRef]

83. Sasaki, M.; Chiwaki, F.; Kuroda, T.; Komatsu, M.; Matsusaki, K.; Kohno, T.; Sasaki, H.; Ogiwara, H. Efficacy of glutathione inhibitors for the treatment of ARID1A-deficient diffuse-type gastric cancers. Biochem. Biophys Res. Commun. 2020, 522, 342-347. [CrossRef]

84. Franklin, M.; Gentles, L.; Matheson, E.; Bown, N.; Cross, P.; Ralte, A.; Gilkes-Immeson, C.; Bradbury, A.; Zanjirband, M.; Lunec, J.; et al. Characterization and drug sensitivity of a novel human ovarian clear cell carcinoma cell line genomically and phenotypically similar to the original tumor. Cancer Med. 2018, 7, 4744-4754. [CrossRef]

85. Tan, T.Z.; Ye, J.; Yee, C.V.; Lim, D.; Ngoi, N.Y.L.; Tan, D.S.P.; Huang, R.Y. Analysis of gene expression signatures identifies prognostic and functionally distinct ovarian clear cell carcinoma subtypes. EBioMedicine 2019, 50, 203-210. [CrossRef]

86. Papp, E.; Hallberg, D.; Konecny, G.E.; Bruhm, D.C.; Adleff, V.; Noe, M.; Kagiampakis, I.; Palsgrove, D.; Conklin, D.; Kinose, Y.; et al. Integrated Genomic, Epigenomic, and Expression Analyses of Ovarian Cancer Cell Lines. Cell Rep. 2018, 25, $2617-2633$. [CrossRef]

87. Caumanns, J.J.; van Wijngaarden, A.; Kol, A.; Meersma, G.J.; Jalving, M.; Bernards, R.; van der Zee, A.G.J.; Wisman, G.B.A.; de Jong, S. Low-dose triple drug combination targeting the PI3K/AKT/mTOR pathway and the MAPK pathway is an effective approach in ovarian clear cell carcinoma. Cancer Lett. 2019, 461, 102-111. [CrossRef] 